\title{
PENERAPAN MODEL PROBLEM BASED LEARNING (PBL) TERHADAP PENINGKATAN KEMAMPUAN BERPIKIR KREATIF MATEMATIS SISWA
}

\author{
Ari Septian ${ }^{1}$, Riki Rizkiandi ${ }^{2}$ \\ ${ }^{1}$ Universitas Suryakancana \\ ariseptian@unsur.ac.id \\ ${ }^{2}$ Universitas Suryakancana \\ rizkiandiriki@yahoo.com
}

\begin{abstract}
ABSTRAK
Tujuan dari penelitian ini untuk mengetahui pengaruh model pembelajaran Problem Based Learning terhadap peningkatan kemampuan berpikir kreatif siswa, dan sikap siswa terhadap pembelajaran matematika dengan menggunakan model pembelajaran Problem Based Learning. Metode yang digunakan dalam penelitian ini adalah quasi experiment dengan desain control group pretest-posttest. Penelitian ini dilaksanakan di SMPN 1 Karangtengah di kelas VIII F sebagai kelas eksperimen dan kelas VIII H sebagai kelas kontrol, Tahun Pelajaran 2016/2017. Instrumen yang digunakan adalah soal tes uraian dan instrumen non tes berupa angket siswa. Data yang diperoleh dari hasil penelitian ini diolah menggunakan bantuan Program SPSS versi 20.0. Hasil penelitian menunjukan bahwa pencapaian dan peningkatan kemampuan berpikir kreatif matematis siswa yang menggunakan model pembelajaran Problem Based Learning lebih baik dari pada siswa yang belajar menggunakan pembelajaran konvensional. Selain itu hasil angket skala sikap menunjukan bahwa pada umumnya siswa bersikap positif terhadap pembelajaran Problem Based Learning.
\end{abstract}

Kata Kunci: Model Problem Based Learning, Berpikir Kreatif Matematis.

\section{PENDAHULUAN}

Pendidikan adalah suatu upaya pengembangan sumber daya manusia yang berkualitas sehingga dapat menghadapi perubahan Ilmu Pengetahuan dan Teknologi di dunia. Untuk mencerdaskan anak bangsa, maka kualitas pendidikan di Indonesia harus dapat ditingkatkan agar dapat bersaing dengan negara-negara lain.

Siswa Indonesia telah mengikuti Trends In International Mathematics and Science Study (TIMSS) pada tahun 2015 dengan hasil tidak menunjukkan banyak perubahan pada setiap keikutsertaannya. Indonesia hanya menduduki rangking 45 dari 50 negara dengan rata-rata skor 397, yang menempatkan Indonesia pada posisi 6 besar dari bawah bersama Jordan, Saudi Arabia, Marocco, South Africa, dan Kuwait (Nizam 2016).

Maka dari itu untuk membangun sumber daya manusia yang berkualitas sehingga dapat bersaing dengan negara lain, terlebih dahulu harus memperbaiki pendidikan di 
Jurnal PRISMA Universitas Suryakancana

Indonesia dengan menguasai semua ilmu pengetahuan yang ada, salah satunya adalah matematika yang sangat penting untuk membangun manusia yang berkualitas karena matematika disebut juga ratunya ilmu yang dapat terkait dengan apapun.

Menurut Ruseffendi (Heruman, 2008) menyatakan bahwa

matematika adalah bahasa simbol, ilmu deduktif, ilmu tentang pola keteraturan, dan struktur yang terorganisasi, mulai dari unsur yang tidak didefinisikan, ke unsur yang didefinisikan, ke aksioma atau postulat, dan akhirnya dalil.

Maka dari itu matematika sangat penting untuk membangun sumber daya manusia yang berkualitas. Akan tetapi kebanyakan orang malas belajar matematika karena beranggapan dalam pembelajaran matematika penuh dengan rumus dan perhitungan yang sukar, sehingga menyebabkan orang enggan untuk belajar matematika sedangkan matematika adalah ilmu yang penting untuk dipelajari. Tetapi dengan terus belajar dan tidak menyerah untuk mencoba memecahkan persoalan yang ada dalam matematika dengan begitu akan terbiasa untuk memecahkan persoalan tersebut dan menganggap matematika mudah.

Belajar menurut Piaget (Dimayanti et al, 2013:13), “pengetahuan dibentuk oleh individu. Sebab individu melakukan interaksi terus-menerus dengan lingkungan“. Proses belajar pada dasarnya merupakan proses interaksi antara dua unsur yaitu siswa yang sedang belajar dan guru yang mengajar, serta berlangsung pada ikatan untuk mencapai tujuan yang dicapai.

Tetapi masih banyak pula kendala yang ditemukan di lapangan, hal ini disebabkan berbagai permasalahan yang muncul dalam proses pembelajaran matematika, baik permasalahan yang berasal dari penggunaaan model pembelajaran, strategi pembelajaran, metode pembelajaran, maupun yang berasal dari lemahnya kemampuan matematis yang dimiliki oleh siswa. Setidaknya, para siswa harus memiliki satu kemampuan matematis yang dapat membantu mereka nanti dalam menyelesaikan permasalahan matematika yang akan mereka temui dalam kehidupan.

Salah satu yang dapat mengatasi permasalahan di atas adalah pemilihan model pembelajaran, karena dengan model pembelajaran yang tepat bisa membuat siswa terdorong berpikir kreatif untuk menjawab persoalan yang ada sehingga siswa tidak akan malas lagi untuk belajar matematika karena sudah menganggap matematika itu sangat mudah dipelajari 
Jurnal PRISMA Universitas Suryakancana

bukan sukar untuk dipelajari atau setidaknya dapat mengurangi tingkat kelemahan siswa pada mata pelajaran matematika.

Ibrahim (2000) menyatakan bahwa

model pembelajaran adalah kerangka konseptual yang melukiskan prosedur yang sistematik dan mengorganisasikan pengalaman belajar untuk mencapai tujuan belajar tertentu dan berfungsi sebagai pedoman para perancang pembelajaran dan para pengajar dalam merencanakan dan melakukan aktivitas pembelajaran.

Dan model pembelajaran yang dirasa tepat yaitu model pembelajaran problem based learning (PBL), yang model pembelajarannya berbasis masalah. Karena dihadapkan langsung dengan permasalahan siswapun akan mencari informasi atau data yang ada untuk memecahkan permasalahan yang dihadapi, dengan demikian siwa akan berpikir kritis dan kreatif supaya permasalahan yang ada dapat terpecahkan.

Selain itu, pengambilan model pembelajaran Problem Based Learning sebagai solusi berdasarkan penelitian Tomy (2012) dengan judul "Meningkatkan Kemampuan Berpikir Kreatif Siswa Dengan Menggunakan Pembelajaran Berbasisi Masalah”. Hasil penelitiannya menyatakan dampak positif terhadap peningkatan berpikir kreatif siswa setelah menggunakan pembelajaran Problem Beased Learning.

Penelitian lain oleh Suparman et al (2015) "Peningkatan Kemampuan Berpikir Kreatif Siswa Melalui Penerapan Model Problem Based Learning” sangat berdampak baik pada peningkatan berpikir kreatif siswa. Cahyaningsih et al (2016) "Pengaruh Penggunaan Model Problem Based Learning Terhadap Karakter Kreatif Dan Berpikir Kritis Dalam Pembelajaran Matematika" ada pengaruh yang signifikan dari model Problem Based Learning (PBL) terhadap peningkatan karakter kreatif dan kemampuan berpikir kritis matematika siswa setelah mengikuti pembelajaran dengan model Problem Based Learning (PBL).

Dari uraian di atas, rumusan dalam penelitian ini adalah Apakah peningkatan kemampuan berpikir kreatif siswa dengan model Problem Based Learning lebih baik dari pada siswa yang menggunakan model pembelajaran konvensional? Bagaimana sikap siswa terhadap model Pembelajaran Problem Based Learning? 
Jurnal PRISMA Universitas Suryakancana

\section{METODOLOGI PENELITIAN}

Metode yang digunakan dalam penelitian ini adalah quasi eksperiment atau eksperimen pura-pura. Desain yang digunakan dalam penelitian ini yaitu desain kelompok kontrol pretest-posttest. Adapun gambaran mengenai rancangan nonequivalent control group design (Sugiyono, 2012) sebagai berikut:

\begin{tabular}{|ccc|}
\hline $\mathrm{O}_{1}$ & $\mathrm{X}$ & $\mathrm{O}_{2}$ \\
\hline & $\mathrm{O}_{3}$ & \\
\hline
\end{tabular}

\section{Gambar 1. Rencana Nonequivalent Control Group Design}

Keterangan:

O1 : pretest group eksperimen

$\mathrm{O} 2$ : posttest group eksperimen

O3 : pretest group kontrol

O4 : posttest group kontrol

$\mathrm{X} \quad$ : pemberian perlakuan

Lokasi penelitian bertempatan di SMP Negeri 1 Karang Tengah. Populasi dalam penelitian ini adalah seluruh siswa kelas VIII SMP Negeri 1 Karang Tengah Tahun Pelajaran 2016/2017. Dari populasi tersebut diambil dua kelas sebagai sampel yaitu kelas VIII F dan VIII H. Salah satu dari kelas tersebut dijadikan sebagai kelas eksperimen yang akan diberikan model pembelajaran Problem Based Learning yaitu kelas VIII F, sedangkan kelas VIII H dijadikan kelas kontrol yang diberikan pembelajaran konvensional.

Instrumen yang digunakan dalam penelitian ini adalah instrumen tes berupa soal tes uraian dan non tes berupa angket skala sikap. Instrumen tes yang diperoleh dari hasil uji coba sebelumnya yang diolah menggunakan software anates uraian untuk mengetahui tingkat validitas, reliabilitas, indeks kesukaran dan daya pembeda. Adapun angket skala sikap digunakan untuk mengetahui bagaimana sikap siswa baik terhadap proses pembelajaran menggunakan model pembelajaran Problem Based Learning maupun terhadap soal-soal yang diberikan dalam pembelajaran yang berkaitan dengan pemahaman konsep matematis siswa. Angket berisi pernyataan-pernyataan tertutup yang terdiri dari 20 pernyataan, yaitu 10 pernyataan bersifat positif dan 10 pernyataan yang bersifat negatif. Data 
Jurnal PRISMA Universitas Suryakancana

yang diperoleh dari penelitian ini berupa data kuantitatif dan data kualitatif. Data kuantitatif berasal dari pretest dan posttest, sedangkan data kualitatif beraal dari angket skala sikap siswa. Pengolahan data kualitatif menggunakan program software SPSS versi 20.0. data input yang dianalisis adalah hasil pretest, posttest, dan gain yang akan diujinormalitas, uji homogenitas, dan uji kesamaan dua rata-rata. Adapun data kualitatif mempresentasikan jumlah responden dari masing-masing pilihan jawaban. Untuk menentukan sikap siswa terhadap setiap pernyataan pada angket mengenai pembelajaran menggunakan model Problem Based Learning digunakan modus yaitu jumlah responden terbanyak pada pilihan setiap pernyataan.

\section{HASIL PENELITAN DAN PEMBAHASAN}

Analisis Data Pretest Kemampuan Berpikir Kreatif Matematis Siswa

Tabel 1. Deskriptif Statistik Data Pretest

\begin{tabular}{cccccc}
\hline Kelas & N & Mean & Std.Deviasi & Minimum & Maksimum \\
\hline Eksperimen & 39 & 17,82 & 6,468 & 0 & 40 \\
Kontrol & 34 & 22,79 & 10,090 & 5 & 45 \\
\hline
\end{tabular}

Berdasarkan Tabel 1, diperoleh rata-rata skor pretest kelas eksperimen adalah 17,82 dengan simpangan baku 6,468. Sedangkan untuk kelas kontrol diperoleh rata-rata 22.79 dengan simpangan baku 10,090 .

Berdasarkan uji statistik menggunakan Mann Whitney karena data tidak berdistribusi normal diperoleh hasil berikut

Tabel 2. Hasil Uji Kesamaan Dua Rata-Rata Data Pretest

\begin{tabular}{cc}
\hline & Pretest \\
\hline Man-Whitney $\boldsymbol{U}$ & 471,500 \\
\hline Wilcoxon $\boldsymbol{W}$ & 1251.500 \\
\hline $\mathbf{Z}$ & $-2,427$ \\
\hline Asmp.Sig (2-Tailed) & 0,015 \\
\hline
\end{tabular}

Berdasarkan tabel 2 diperoleh kesimpulan bahwa nilai rata-rata kemampuan awal kelas eksperimen dan kelas kontrol berbeda. 


\section{Analisis Data Posttest Kemampuan Berpikir Kreatif Matemtis Siswa}

Tabel 3. Deskrptif Statistik Data Posttest

\begin{tabular}{cccccc}
\hline Kelas & N & Mean & Std.Deviasi & Minimum & Maksimum \\
\hline Eksperimen & 39 & 78,33 & 15,058 & 50 & 100 \\
\hline Kontrol & 34 & 49.26 & 17,928 & 30 & 100
\end{tabular}

Berdasarkan Tabel 3, diperoleh rata-rata skor posttest kelas eksperimen adalah 78,33 dengan simpangan baku 15,058. Sedangkan untuk kelas kontrol diperoleh rata-rata 49.26 dengan simpangan baku 17,928.

Berdasarkan uji statistik menggunakan Mann Whitney karena data tidak berdistribusi normal diperoleh hasil berikut

Tabel 4. Hasil Uji Kesamaan Dua Rata-Rata Data Posttest

\begin{tabular}{cc}
\hline & Posttest \\
\hline Man-Whitney $\boldsymbol{U}$ & 131,500 \\
\hline Wilcoxon $\boldsymbol{W}$ & 726.500 \\
\hline $\mathbf{Z}$ & $-5,957$ \\
\hline Asmp.Sig (2-Tailed) & 0,000 \\
\hline
\end{tabular}

Berdasarkan tabel 4 diperoleh kesimpulan bahwa terdapat perbedaan kemampuan akhir berpikir kreatif matematis siswa yang belajar menggunakan model pembelajaran Problem Based Learning (PBL) dan siswa yang belajar dengan metode pembelajaran konvensional berbeda. Hal ini disebabkan karena efektivitas Problem Based Learning (PBL) dalam pembelajaran di kelas sangat baik. Keinginan siswa dalam mengeksplorasi kemampuan berpikir kreatif, bekerjasama, dan memahami permasalahan sehari-hari, serta mengaitkan dengan ilmu matematika menjadi tolak ukur keberhasilan proses pembelajaran di kelas.

\section{Analisis Indeks Gain Kemampuan Berpikir Kreatif Matematis Siswa}

Tabel 5. Deskriptif Statistik Data Indeks Gain

\begin{tabular}{cccccc}
\hline Kelas & N & Minimum & Maksimum & Mean & $\begin{array}{c}\text { Standar } \\
\text { Deviasi }\end{array}$ \\
\hline Eksperimen & 39 & 0,38 & 1,00 & 0,7374 & 0,1830 \\
\hline Kontrol & 34 & 0,09 & 1,00 & 0,3442 & 0,2369 \\
\hline
\end{tabular}


Jurnal PRISMA Universitas Suryakancana

Berdasarkan Tabel 5, diperoleh rata-rata skor indeks gain kelas eksperimen adalah 0,7374 dengan simpangan baku 0,1830. Sedangkan untuk kelas kontrol diperoleh rata-rata 0,3442 dengan simpangan baku 0,2369.

Berdasarkan uji statistik uji kesamaan dua rata-rata menggunakan Mann Whitney karena data tidak berdistribusi normal diperoleh hasil berikut

Tabel 6. Uji Kesamaan Dua Rata-Rata Indeks Gain

\begin{tabular}{cc}
\hline & Gain \\
\hline Man-Whitney $\boldsymbol{U}$ & 127,000 \\
\hline Wilcoxon $\boldsymbol{W}$ & 722,000 \\
\hline $\mathbf{Z}$ & $-5,968$ \\
\hline Asmp.Sig (2-Tailed) & 0,000 \\
\hline
\end{tabular}

Berdasarkan tabel 6 diperoleh kesimpulan bahawa peningkatan kemampuan berpikir kreatif matematis siswa yang mengikuti pembelajaran dengan menggunakan model pembelajaran Problem Based Learning (kelas eksperimen) lebih baik dari pada siswa yang mengikuti pembelajaran secara konvensional (kelas kontrol). Hal ini disebabkan karena siswa melakukan aktivitas yang berorientasi pada murid, bukan pada guru. Peningkatan kemampuan berpikir kreatif siswa didasarkan pada kemampuan guru dalam mengelola kelas. Ditambah dengan keyakinan siswa akan pekerjaan yang dilakukan saat pembelajaran.

\section{Analisis Angket Skala Sikap Siswa yang Menggunakan Model Pembelajaran Problem Based Learning Terhadap Kemampuan Berpikir Kreatif Matematis Siswa}

Tabel 7. Presentase Total Sikap Siswa Terhadap Pembelajaran dengan Menggunakan Model

Problem Based Learning

\begin{tabular}{ccc}
\hline Sikap Positif & Sikap Negatif & Keterangan \\
\hline $\mathbf{9 1 , 2 8 \%}$ & $8,72 \%$ & Pada Umumnya Positif \\
\hline
\end{tabular}

Berdasarkan tabel 7 diatas diperoleh modus presentase sikap siswa sebesar 91,28\% yaitu pada sikap positif, maka dapat diartikan bahwa pada umumnya siswa bersikap positif terhadap pembelajaran Problem Based Learning. Hal ini terlihatdari beberapa indikator penilaian sikap yang menilai bahwa dengan model Problem Based Learning (PBL) siswa dapat memahami persoalan yang diberikan oleh guru, sehingga dapat memecahkan masalah. Selain itu, siswa dapat melakukan eksplorasi terhadap kemampuan berpikir kreatif 
Jurnal PRISMA Universitas Suryakancana

matematis. Siswa dapat memahami, mengkomunikasikan, dan menafsirkan atas persoalan matematis yang dihadapi .

\section{KESIMPULAN}

Berdasarkan hasil penelitian dan pembahasan, dapat disimpulkan bahwa peningkatan kemampuan berpikir kreatif siswa yang belajar dengan model pembelajaran Problem Based Learning lebih baik daripada siswa yang belajar dengan pembelajaran konvensional dan secara umum sikap siswa terhadap pembelajaran matematika dengan menggunakan model pembelajaran Problem Based Learning adalah positif.

\section{REFERENSI}

Cahyaningsih, U, \& Ghufron, A. (2016). Pengaruh Penggunaan Model Problem Based Learning Terhadap Karakter Kreatif Dan Berpikir Kritis Dalam Pembelajaran Matematika. Jurnal Pendidikan Karakter (1)

Dimayanti. (2013). Belajar Dan Pembelajaran. Jakarta: PT Rineka Cipta

Heruman. (2008). Model Pembelajaran Matematika Di Sekolah Dasar. Bandung: Remaja Rosdakarya.

Nizam. (2016). Hasil-Hasil Asesmen Belajar Dari Hasil UN PISA TIMSS INAP.Tidak Diterbitkan. [Daring] URL: puspendik. kemendikbud. go. Id /seminar/

Suparman Et al. (2015). Peningkatan Kemampuan Berpikir Kreatif Siswa Melalui Penerapan Model Problem Based Learning. Dalam Jurnal Bioedukasi [Daring], Vol $32 \quad$ No $2 . \quad$ Tersedia: http://Ejournal.Unkhair.Ac.Id/Index.Php/Bioedu/Article/Download/109/83.

Tomy. (2012). Meningkatkan Kemampuan Berpikir Kreatif Siswa Dengan Menggunakan Pembelajaran Berbasisi Masalah. Dalam Jurnal Pendidikan Matematia [Daring], Vol.1 No.1 Part 3: 22-26. Tersedia:http://Ejournal.Unp.Ac.Id/Students/Index.Php/Pmat/Article/Download/11 $52 / 844$ 